\title{
Pastoral Attitudes that Predict Numerical Church Growth
}

\author{
David R. Dunaetz \\ Azusa Pacific University \\ ddunaetz@apu.edu \\ Kenneth E. Priddy \\ KPG Ministries \\ kenpriddy.com@gmail.com
}

\begin{abstract}
The attitudes of 92 head pastors were measured concerning 20 ministry-relevant ideas and practices, as well as information about their church's present numerical growth. A statistical analysis found four pastoral attitudes that predict positive or negative numerical church growth. Positive predictors of numerical church growth were strong beliefs that 1) personal and corporate prayer are important and 2) transfer growth is an indicator of congregational health. Negative predictors of numerical church growth were strong beliefs in 1) the importance of preaching and 2) the importance of outreach to the community. The practical implications of these findings are discussed in light of evangelical theology.
\end{abstract}

Pastors, through their training and experience, develop attitudes about a multitude of ministry related concepts, practices, and beliefs. This study examines various pastoral attitudes in order to find those that are associated with a numerically growing church.

At the most fundamental level, attitudes are personal evaluations of people, objects, practices, policies, or beliefs (Ajzen \& Fishbein, 1977); they are basically how much we like something, whether the something be concrete (like a person) or abstract (like an idea). People's attitude toward this something can be placed on a scale, from most favorable to most unfavorable.

Attitudes are very closely associated with people's affect, behavior, and cognition (the ABC model of attitudes; Eagly \& Chaiken, 1998). Affect is the set of feelings we experience when we think about or experience something; these feelings largely depend on our attitudes. For example, our attitude toward evangelism will influence how we feel when a speaker starts talking about evangelism.

Our behavior, though not always, is also related to our attitudes. In the long run, we are able to be predict a person's behavior from his or her attitudes; a person's attitude toward social work might not predict what he or she does this afternoon, but there is a good possibility that it will predict long term behavioral patterns.

Similarly, our cognitions (or thoughts) are related to our attitudes. If I study what the Bible has to say about discipleship, my thoughts may lead me to change my attitudes towards various discipleship programs that I examine. Similarly, if I have a very strong attitude about a 
specific discipleship program, this attitude may influence what biblical passages I use to evaluate it. In any case, our cognitions enable our attitudes to be changed to various degrees at least some of the time (Bohner \& Dickel, 2011; Kelman, 1961). Unlike personality traits which tend to be stable across the lifespan (McCrae \& Costa, 2003), attitudes often change, typically through persuasion or emotional appeal (Petty \& Cacioppo, 1986).

The goal of this study is to find out what attitudes held by pastors are associated with a numerically growing church. A positive attitude toward some concepts may predict the numerical growth of a church; these would be positive predictors. A positive attitude toward other concepts may predict the numerical decline of a church; these would be negative predictors.

The numerical growth of a church is, at the popular level, considered positive in most situations (e.g., Easum \& Cornelius, 2006) because it may provide evidence of effective evangelism, correct theology, and obedience to God. However, others have critiqued an emphasis on numerical growth (Towns, Van Gelder, Van Engen, Van Rheenen, \& Snyder, 2004; Van Rheenen, 2006), arguing that numerical growth may be a result of a diluted Gospel or poor theology, rather than a sign of accomplishing God's will. Nevertheless, many, if not most, evangelical churches continue to measure attendance at their weekly worship services. The point of view of this paper is that the goal of numerical growth is not growth in itself, but that each one unit increase in church attendance represents an individual who is infinitely valuable to God (Luke 12:7). It is the responsibility of church leaders to help as many individuals as possible become disciples of Jesus Christ (Matt. 28:19-20).

\section{Method}

A secondary data analysis (Glass, 1976) was performed on data collected by KPG Ministries from 92 senior/lead pastors of evangelical churches in the spring of 2011 (Priddy, 2012). The purpose of the original study was to understand the dynamics of church turnaround, the process by which churches in long term numerical decline or stagnation begin to grow once again. This present study simply examines pastoral attitudes in order to find those that predict numerical church growth in the churches that participated in the study.

\section{The Sample}

Usable data was available on 88 evangelical churches, spread across the continental United States, especially in the Southern and Mid-Atlantic States. Half of these churches were associated with the Evangelical Presbyterian Church and most of the others were associated with the Associate Reformed Presbyterian Church or the Christian and Missionary Alliance. All three denominations are theologically conservative and evangelical with a very high view of the authority of Scripture. In the original study (Priddy, 2012), email invitations were sent to approximately 700 pastors, of which 93 responded by completing an online survey. The average present weekly attendance of the churches for which data was collected was 163 adults (compared to 146 five years earlier). The reporting pastors had an average of 19 years of ministry experience, of which 8.5 years were spent as the senior/lead pastor of their current church. 


\section{Measures}

To analyze the relationship between pastoral attitudes and numerical church growth empirically, it is necessary to have data on both church growth and pastoral attitudes. By quantifying this information, we can use statistical analyses that reduce the subjectivity and bias that can easily interfere with the interpretation of the information collected. Statistical analyses also help us clarify how certain we can be of our conclusions.

Numerical Church Growth. Two items in the pastoral survey allowed a church growth statistic to be calculated for each church: "What is your current church's average adult attendance in your primary weekly worship service or services?" and "What was your current church's average attendance in your primary weekly worship service or services over the past year? The calculated one-year growth rate $^{1}$ ranged from - .80 (an $80 \%$ loss/year) to 1.08 (a $108 \%$ growth/year). The average one-year growth rate was .099 (almost a 10\% increase in attendance in the past year).

To check the validity of this one-year growth rate, other data from the survey can be used. The average transfer growth rate was .087 and the average conversion growth rate was .050. This implies an attrition rate of .038, meaning that in a typical year, a bit less than $4 \%$ of the congregation died, moved, or left the church for some other reason. This figure is lower than what might be expected (cf. Dunaetz (2011) who found that approximately $8 \%$ of church attenders who did not die or move left the congregation each year), but it is possible that these churches were more stable than others studied.

Another check comes from the reported five-year growth rate which averaged 2.9\%/year. Comparing the five-year and one-year growth rates indicates that either the churches that participated in the survey are currently doing better than they were in the past (a reasonable assumption; such pastors would be more motivated to participate in the survey) or that the pastors were overly optimistic about the current state of their church (another reasonable possibility; Alicke \& Govorun, 2005; Krueger, 1998). Nevertheless, 54\% of the pastors reported a one-year growth rate that was either zero or negative, indicating that any unrealistic optimism was relatively limited in scope.

\section{Attitudes}

Two sets of items were used to measure pastoral attitudes. The first set asked pastors to indicate on a scale of one to ten ( 10 being the most important) how important different ministries and concepts were to them. For example, "On a scale of 1-10, how important is shepherding the congregation?" The second set of items used a four point Likert scale $(1=$ strongly disagree, $4=$ strongly agree) to measure pastors' attitudes toward various ministry related concepts, such as "I am personally committed to the numerical growth of my congregation" and "The emergence of mega churches in the United States has been a positive influence for the cause of Christ."

\section{Descriptive Statistics}

The twenty attitudes measured, their mean scores, the range of responses, and the degree to which each item correlates with present church growth are found in Table 1. Several notable observations can be made from these data.

\footnotetext{
${ }^{1}$ The one-year growth rate was calculated using the formula:

Present Growth Rate $=2 \times$ (Present Attendance - Past Year's Average Attendance) $/$ Present Attendance. This formula assumes that any changes in attendance over the last year occurred in a regular, linear fashion so that the Past Year's Average Attendance represents the average attendance of 6 months ago.
} 
Table 1

\section{Descriptive Statistics of the Attitudes Measured}

\begin{tabular}{|c|c|c|c|c|}
\hline Attitude Name & Survey Item & $\begin{array}{c}\text { Range of } \\
\text { Reported } \\
\text { Scores }\end{array}$ & $\begin{array}{l}\text { Mean } \\
\text { Score }\end{array}$ & $\begin{array}{c}\text { Correlation } \\
\text { with One- } \\
\text { Year Growth } \\
\text { Rate }\end{array}$ \\
\hline \multicolumn{5}{|c|}{ Items Measuring Importance (Scale: $1-10,10=$ Most Important) } \\
\hline Stewardship & $\begin{array}{l}\text { How important is financial stewardship of church } \\
\text { assets? }\end{array}$ & $4-10$ & 8.4 & .03 \\
\hline Shepherding & How important is shepherding the congregation? & $2-10$ & 8.6 & .01 \\
\hline Foreign Missions & How important is supporting foreign missions? & $3-10$ & 8.2 & -.09 \\
\hline Outreach & $\begin{array}{l}\text { How important is providing outreach to the local } \\
\text { community? }\end{array}$ & $2-10$ & 8.5 & -.15 \\
\hline Worship & How important is Christ-centered worship? & $8-10$ & 9.7 & -.14 \\
\hline Home Missions & How important is supporting domestic missions? & $2-10$ & 7.8 & .05 \\
\hline Preaching & How important is the preaching of the Word? & $8-10$ & 9.8 & $-.22 *$ \\
\hline Evangelism & How important is evangelizing the local community? & $3-10$ & 8.5 & -.03 \\
\hline Prayer & How important is personal and corporate prayer? & $4-10$ & 8.8 & .09 \\
\hline Conversion Growth & $\begin{array}{l}\text { How important is growing the congregation } \\
\text { numerically by conversion? }\end{array}$ & $1-10$ & 8.1 & -.02 \\
\hline \multicolumn{5}{|c|}{ Items Measuring Belief (Scale: 1-4, $4=$ Strongly Agree) } \\
\hline Numerical Growth & $\begin{array}{l}\text { I am personally committed to the numerical growth of } \\
\text { my congregation. }\end{array}$ & $1-4$ & 3.5 & .14 \\
\hline Few Conversions & $\begin{array}{l}\text { Low conversion growth indicates poor congregational } \\
\text { health. }\end{array}$ & $1-4$ & 2.9 & -.13 \\
\hline Older Literature & $\begin{array}{l}\text { I am well acquainted with church growth literature of } \\
\text { the last quarter of the } 20 \text { th century. }\end{array}$ & $2-4$ & 3.2 & -.09 \\
\hline Transfer Growth & $\begin{array}{l}\text { Transfer growth is an indicator of positive } \\
\text { congregational health. }\end{array}$ & $1-3$ & 2.4 & $.23 *$ \\
\hline $\begin{array}{l}\text { Preaching vs. } \\
\text { Evangelism }\end{array}$ & $\begin{array}{l}\text { The proper preaching of the Word is of greater } \\
\text { importance than outreach and evangelism. }\end{array}$ & $1-4$ & 2.6 & -.12 \\
\hline Growth Mandated & $\begin{array}{l}\text { The numerical growth of my congregation is not a } \\
\text { biblical mandate. }\end{array}$ & $1-4$ & 2.2 & -.14 \\
\hline Mega Churches & $\begin{array}{l}\text { The emergence of mega churches in the United States } \\
\text { has been a positive influence for the cause of Christ. }\end{array}$ & $1-4$ & 2.4 & .04 \\
\hline Evangelism Gift & $\begin{array}{l}\text { Evangelism is primarily the responsibility of those } \\
\text { who have the gift of evangelism. }\end{array}$ & $1-4$ & 1.7 & .14 \\
\hline $\begin{array}{l}\text { Shepherding vs. } \\
\text { Evangelism }\end{array}$ & $\begin{array}{l}\text { The shepherding of the congregation is of greater } \\
\text { importance than local outreach and evangelism. }\end{array}$ & $1-4$ & 2.3 & .04 \\
\hline Modern Literature & $\begin{array}{l}\text { I am well acquainted with current church growth } \\
\text { literature. }\end{array}$ & $1-4$ & 2.9 & -.04 \\
\hline
\end{tabular}

Note: $*$ indicates a significant relationship $(p<.05$, two tails).

Among the items measuring pastoral attitudes toward various ministry elements (those measured on a $1-10$ scale), two had a significantly higher average and had a much more narrow range of responses: Christ-centered worship and preaching the Word. This indicates that the entire sample values these ministry elements, most likely due to a common set of evangelical values. The lowest priority given to each of these two items was 8 out of 10 . This means that those who gave low scores (i.e., 8), are still very committed to Christ-centered worship and preaching the word. The attitudes toward the other ministry items varied greatly, indicating much less influence from a common value system. 
Table 1 reports the correlation of these attitudes with the one-year growth rate of the church. A correlation is a measure of how two phenomena are related to each other. It can range in value from -1 to +1 . Positive correlations indicate that, on the average, as one value goes up, the other does also. Negative correlations indicate that the two phenomena being measured move in opposite directions; as one goes up, the other goes down, and vice-versa. A zero correlation indicates that the two are not related. The closer a correlation gets to +1 or -1 , the stronger it is. A correlation of +1 indicates that as one goes up, the other always goes up also. A correlation of -1 indicates that as one goes down, the other always goes up, and vice-versa.

When looking at correlations between attitudes and concrete outcomes like present church growth, the correlations are not likely to be very strong. Present church growth depends on a multitude of factors (e.g., the personality, abilities, and attitudes of church members, the personality, abilities, and attitudes of lay church leaders, the characteristics of the neighborhood, the resources that the church has available, etc.), most of which are not strongly related to the lead pastor's attitudes. So in this type of research, we should not expect strong correlations; we are more interested in the sign of the correlation (In what way is an attitude related to the oneyear church growth rate?) and deciding if we can be certain that we have the sign of the correlation correct (Can we be sure that the correlation is not just spurious or random?). We can use a test of significance to test whether we can be certain or not about the sign of the correlation. In statistical analyses, we use a probability $(p)$ level of .05 as the cutoff point. This means that, given the sample size we are using, if there is less than a 5\% chance that we could have obtained such a correlation by chance, we say the results are significant. Results that are not significant might very well reflect a true relationship, but there is more than a $5 \%$ chance that we could have obtained such results by chance. Any significant correlation that we find indicates that we can be reasonably certain that a pastoral attitude is related to present church growth in the direction indicated.

Table 1 indicates that there are only two significant correlations, one in a negative direction and the other in a positive direction. As belief that preaching the Word is important increases, the one-year growth rate decreases. As belief that transfer growth is a positive sign of church health increases, the one-year growth rate increases. These results will be discussed thoroughly later. However, right now, we should note that there is another, even more powerful tool (relative to correlations) that can be used to find significant relationships between phenomena. Multiple linear regression tests for significant relationships that are conceptually similar to correlations. However, the results are more powerful than simple correlations because it removes the overlap among and the interference between the various predictors in order to see which ones really count. Thus in order to discover more thoroughly which pastoral attitudes predict numerical church growth, our primary analyses will be done with multiple linear regression.

\section{Results}

When we have data on multiple variables that might predict an outcome that we have measured (such as the one-year church growth rate), multiple linear regression (Cohen, 2003) is the standard statistical technique to use because of its power to control for the relationships that predictor variables have with one another. For example, temperature, ice cream consumption, and the crime rate are all positively and significantly correlated with each other. When one tends to go up, the others do as well. If we wanted to predict a crime rate, we could use either 
temperature or ice cream consumption to do so. However, logically it makes more sense that high temperatures lead to a higher crime rate (heat makes people uncomfortable and more agressive; Anderson, 1989). Ice cream consumption is only indirectly related to crime rates. If we performed a multiple linear regression analysis on the data to model or predict crime rates, we would most likely find that high temperatures remain a significant predictor but not ice cream consumption. Thus multiple linear regression is a more powerful tool than correlation for discovering potential predictors of an outcome that interests us, in our case, the one-year growth rate of a church.

A stepwise multiple regression analysis was used to discover which attitudes (of the twenty measured) significantly predict the one-year growth rate of a church. This type of multiple regression analysis creates a model by adding the strongest predictors to it one at a time until the improvement in the model's predicting power is no longer significant (i.e., the chances of that type of improvement happening by chance is greater than 5\%). Rather than producing correlations, these analyses produce standardized coefficients of the regression model which are called $\beta$. The meaning of $\beta$ and correlation is essentially the same. The sign of $\beta$ indicates the direction of the relationship and the magnitude of $\beta$ indicates the strength of the relationship. Attitudes that do not produce a significant $\beta$ might still influence present church growth, but we cannot be sufficiently sure to make a definite conclusion and so they are not included in the model. Table 2 provides a list of the four significant predictors of current church growth resulting from stepwise multiple regression and their $\beta$ s.

\section{Table 2}

\section{Significant Predictors of One-Year Growth Rate}

\begin{tabular}{|c|c|c|}
\hline Attitude Name & Survey Item & $\beta$ \\
\hline Outreach & $\begin{array}{l}\text { How important is providing outreach to } \\
\text { the local community? }\end{array}$ & $-.22 *$ \\
\hline Preaching & $\begin{array}{l}\text { How important is the preaching of the } \\
\text { Word? }\end{array}$ & $-.33 *$ \\
\hline Prayer & $\begin{array}{l}\text { How important is personal and corporate } \\
\text { prayer? }\end{array}$ & $.33^{*}$ \\
\hline $\begin{array}{l}\text { Transfer } \\
\text { Growth }\end{array}$ & $\begin{array}{l}\text { Transfer growth is an indicator of } \\
\text { positive congregational health. }\end{array}$ & $.28 *$ \\
\hline
\end{tabular}

\section{Discussion}

This study examined data collected from pastors of evangelical churches. Data on various pastoral attitudes and the one year growth rate of churches were statistically analyzed to discover 
which attitudes could be used to predict the numerical growth of a church. The analysis revealed four attitudes that were significant predictors of a church's growth rate. Especially strong beliefs that biblical preaching is important and that outreach to the local community is important were predictors of a negative growth rate. Beliefs that transfer growth is healthy and that prayer is important were predictors of a positive growth rate. Some of these findings go against common evangelical beliefs and all require further discussion and research.

\section{The Four Attitudes that Predict Numerical Growth}

Preaching the Word. The most seemingly controversial finding of this study is that a strong belief in the importance of preaching the Word is a predictor of a negative growth rate, that is, a shrinking membership. Not only does this seem to contradict evangelical theology which upholds the preaching of the Word of God, but it seems to contradict other studies which clearly indicate that churches that place less of an emphasis on the Bible are in decline while conservative churches are growing (Demerath, 1995). However, it should be noted that all churches in this study are conservative evangelical churches. They are not representative of all U.S. churches. All the pastors in the study reported at least an 8 on a scale of 10 to the question "How important is preaching the Word?" So this study is only examining a difference in attitude among pastors who all believe the Word of God is extremely important.

The average strength of a pastor's attitude toward preaching the Word was 9.8 out of 10 . However, a significant difference can be noted among pastors who reported a 10 and those who reported less than 10. Among the 13 churches where the pastor reported an 8 or a 9 , the average growth rate was $23.4 \%$ year. Among the 75 churches where the pastor reported a 10, the average growth rate was only $7.5 \%$ /year. It should be noted in all 9 churches that reported a negative growth rate (in contrast to stagnation or a positive growth rate), the pastor reported a 10 for this item.

There are several possible reasons for this phenomenon. An over-emphasis on preaching (such as spending 20 or more hours per week on sermon preparation) may limit pastoral involvement in other activities that are necessary for a church to grow numerically. Another possibility is that a high emphasis on preaching is perhaps, but not necessarily, symptomatic of a limited pastoral skill set; perhaps some of these pastors are limited in what they are able to do and thus spend their time doing one of the relatively few things for which they are well equipped. A high emphasis on preaching may also indicate a limited repertoire of evangelistic methods; perhaps some of these pastors are not aware of other ways to communicate the Gospel effectively.

This lower rate of growth could also be associated with systemic issues, related more to the church than to the pastor. Perhaps churches that call pastors because of their high commitment to preaching are less attractive to non-believers or other non-churched people. This could perhaps be the case in elderly congregations or congregations that are culturally distant from the surrounding community. Such pastors may have been selected to respond to the needs of the established church and maintain traditions, rather than to relate to non-Christians or respond to the needs of new or younger Christians. It is also possible that some pastors place such a high priority on preaching because they are in churches that have little potential for numerical growth due to their lack of attractiveness to outsiders. Activities designed to attract others to the church may be doomed to failure, so the pastor may "play it safe" and place a greater emphasis on preaching, for which he receives positive feedback and encouragement from the present members. 
Transfer Growth as a Sign of Church Health. On the average, the more pastors agreed with the statement "Transfer growth is an indicator of positive congregational health," the faster their churches were growing. However, it should be noted, that no pastor indicated that he "strongly agreed" with the statement, perhaps because transfer growth is clearly not biblically mandated and because it is easy to conceive of unbiblical and even ungodly ways to attract transfer growth. About half the pastors agreed that transfer growth was a sign of congregational health, and their churches reported an annual growth rate of $17.0 \%$. About half the pastors disagreed or strongly disagreed, and their average annual growth rate was $3.6 \%$.

There are several possible reasons that explain why this attitude predicts the one-year growth rate of a church. Some pastors may believe that people will tend to go to churches that meet their needs and expectations in culturally relevant ways. Because these pastors may believe it is healthy to structure their church's programs around these needs and expectations, these churches may attract more transfer growth than those who don't share this belief. They may also believe that most Christians would not choose to go to an unhealthy church because God's Spirit would lead them away, concluding that transfer growth is therefore a sign of God's blessing (cf. I John 2:27).

Another possible factor is cognitive dissonance that occurs when people realize that there is some sort of contradiction in their beliefs and/or behaviors. When people experience cognitive dissonance, they tend to adjust their beliefs, behaviors, and situations so as to remove these unsettling contradictions (Festinger, 1957). When pastors look at their church's numerical growth, cognitive dissonance may occur and influence their attitude toward transfer growth. Since most pastors want to believe that their churches are healthy, pastors who attract transfer members are likely to believe that this is a sign of good health, while pastors who do not attract transfer members are likely to believe that transfer growth is not a sign of good health. Both attitudes would support their belief that the church is healthy.

Underlying such contradictory beliefs may be confusion over the nature of numerical church growth. A pastor may not distinguish between transfer and conversion growth. The two may be confounded in his thinking and be viewed as equally valuable. Not distinguishing between transfer and conversion growth may lead to a greater emphasis on activities that attract Christians from other churches because transfer growth may be easier to achieve than conversion growth.

Personal and Corporate Prayer. Believing in the importance of personal and corporate prayer is also a positive predictor of present church growth, as would be expected from evangelical theology (John 14:13-14, James 5:16). There are several potentially overlapping mechanisms that can explain this relationship. The first is that God may respond to the prayers of members of a Christian community who seek his will; he may motivate people to come to such a church and lead its members to meet the new people's needs, which in turn may motivate the newcomers to join the church. Secondly, a church characterized by prayer might be more motivated to live in accordance with biblical principles, making itself more attractive to newcomers. A third mechanism would be that a growing congregation may push the church leadership toward greater dependency on God, motivating them to come before him as they sense their need for his power to minister to the newcomers adequately. Each of these mechanisms may play a role in this relationship.

The item measuring this attitude includes both corporate and personal prayer. Although these two forms of prayer are possibly correlated in churches, the effects of one type might be more important than the effects of the other. This current study did not separate the two. 
Providing Outreach to the Local Community. Believing that it is important to provide outreach to the local community is a negative predictor of the one-year church growth rate. This goes against the intuitive belief that more outreach is needed to lead more people to Christ. However, it should be noted that there is a difference between outreach and evangelism. Outreach is simply developing relationships with people outside of an organization; it is a common goal and practice of non-Christian organizations. Outreach in itself does not necessarily communicate the Gospel nor make disciples. If outreach goes well, from a biblical perspective, it will lead to evangelism and making disciples. However, outreach may simply drain time and energy from a church's program and a pastor's schedule. If this is the case, such use of limited resources could easily reduce the potential for church growth.

Outreach ministries that may be ineffective and wasteful need to be identified. If they do not lead to a meaningful communication of the gospel and to people becoming disciples of Jesus Christ, they should be considered as candidates for a thorough evaluation of whether or not they should continue. This is a delicate issue because many outreach activities make the participants feel good about themselves, regardless of whether or not the gospel is communicated. In addition, modern western culture discourages a clear, persuasive presentation of the Gospel. It is therefore less culturally stressful for both pastors and church members to live by the pseudoFrancis of Assisi saying, "Preach the gospel at all times; when necessary, use words" (Galli, 2002) which justifies social involvement without a clear proclamation of the Gospel, contrary to the example of both Jesus and Paul. The data in this study suggests that this type of attitude is associated with a lower rate of church growth.

Furthermore, outreach often focuses on individuals who are not likely or able to join the church. Many white, English-speaking, American churches are socially distant from the homeless, Spanish speakers, or the black community. Neither the existing church nor the target community may have a desire to go beyond surface level or financial interaction with each other. Language and dialectical differences, as well as other behavioral differences associated with culture, present stronger barriers to deep relationships than many would like to admit (cf. the Tower of Babel in Genesis 11; Tajfel \& Turner, 1986; Tsui, Egan, \& O'Reilly, 1992).

Nevertheless, a local church is called to be a blessing to all (Phil. 2:15-16). The goal of much community outreach is to make the lives of those living around the church better by making education, social services, or physical resources available to those who need them. A local church should also have the same primary mission as Jesus, "to seek and to save the lost" (Luke 19:10). This mission should motivate a church to combine outreach with evangelism, which will respond to the most important human need, the need for eternal life through a relationship with Jesus Christ.

Another possible cause of the negative relationship between outreach and numerical growth concerns how a dying church might respond to its decline. A church that is declining for any number of reasons (a congregation with a mortality rate higher than the birth rate, a program that no longer responds to the needs of a community, a membership which is not socially attractive, etc.) might feel the need to develop relationships with outsiders more than churches that are already growing. In this case, outreach might be beneficial to the church and slow its decline, if it leads to effective evangelism and disciple making.

\section{Limitations}

This study was restricted to conservative, evangelical churches with a relatively limited range of denominations represented. Churches in other conservative, evangelical denominations 
would likely experience similar relationships between pastoral attitudes and numerical growth. Churches of other theological orientations would undoubtedly show different growth patterns associated with pastoral attitudes.

This study was also limited due to its correlational nature. We must distinguish between correlation and causation, as correlation does not imply causation. As noted in the discussion, we cannot be sure if pastoral attitudes affect the numerical growth of churches or if numerical growth affects pastoral attitudes. It is possible, if not likely, that both influence each other. The only way that these questions of causality can be addressed with certainty is through additional studies that are experimental in nature, where some pastors are instructed or persuaded to make certain attitudinal changes, and others are not.

\section{Conclusion}

This study addressed the relationship between pastoral attitudes and the one-year rate of growth in conservative evangelical churches. Emphases on preaching the Word and outreach to the community predicted lower numerical growth. Positive attitudes toward prayer and transfer growth predicted higher rates of growth. This information can be used to help pastors evaluate their own attitudes in light of their churches' programs. An adjustment of a pastor's attitudes, followed by the necessary changes in practice, might lead to a more effective ministry and greater numerical growth in the church. 


\section{References}

Ajzen, I., \& Fishbein, M. (1977). Attitude-behavior relations: A theoretical analysis and review of empirical research. Psychological bulletin, 84, 888-918.

Alicke, M. D., \& Govorun, O. (2005). The better-than-average effect. In M. D. Alicke, D. A. Dunning \& J. I. Krueger (Eds.), The self in social judgment (pp. 85-106). New York, NY: Psychology Press.

Anderson, C. A. (1989). Temperature and aggression: Ubiquitous effects of heat on occurrence of human violence. Psychological Bulletin, 106, 74-96.

Bohner, G., \& Dickel, N. (2011). Attitudes and attitude change. Annual Review of Psychology, 62, 391-417.

Cohen, J. (2003). Applied multiple regression/correlation analysis for the behavioral sciences. Mahwah, NJ: Lawrence Erlbaum.

Demerath, N. J. (1995). Cultural victory and organizational defeat in the paradoxical decline of liberal protestantism. Journal for the scientific study of religion, 34, 458-469.

Dunaetz, D. R. (2011). Personality and conflict style: Effects on membership duration in voluntary associations. Saarbrücken, Germany: Lambert Academic Press.

Eagly, A. H., \& Chaiken, S. (1998). Attitude structure and function. In D. T. Gilbert, S. T. Fiske \& G. Lindzey (Eds.), The handbook of social psychology (4th ed., pp. 269-322). Boston, MA: McGraw Hill.

Easum, W. M., \& Cornelius, B. (2006). Go big: Lead your church to explosive growth. Nashville, TN: Abingdon Press.

Festinger, L. (1957). A theory of cognitive dissonance. Evanston, IL: Row, Peterson and Co.

Galli, M. (2002). Francis of Assisi and his world. Downers Grove, IL: InterVarsity Press.

Glass, G. V. (1976). Primary, secondary, and meta-analysis of research. Educational researcher, $5,3-8$.

Kelman, H. C. (1961). Processes of opinion change. Public Opinion Quarterly, 25, 57-78.

Krueger, J. (1998). Enhancement bias in descriptions of self and others. Personality and Social Psychology Bulletin, 24, 505-516.

McCrae, R. R., \& Costa, P. T., Jr. (2003). Personality in adulthood (2nd ed.). New York, NY: Guilford Press.

Petty, R. E., \& Cacioppo, J. T. (1986). Communication and persuasion: Central and peripheral routes to attitude change. New York, NY: Springer.

Priddy, K. E. (2012). Chruch turnaround: Perspectives, principles, and practices. Great Commission Research Journal, 3, 161-176.

Tajfel, H., \& Turner, J. C. (1986). The social identity theory of intergroup behavior. In S. Worchel \& W. G. Austin (Eds.), Psychology of intergroup relations (2nd ed., pp. 7-24). Chicago, IL: Nelson-Hall.

Towns, E. L., Van Gelder, C., Van Engen, C., Van Rheenen, G., \& Snyder, H. (2004). Evaluating the church growth movement: 5 views. Grand Rapids, MI: Zondervan.

Tsui, A. S., Egan, T. D., \& O'Reilly, C. A., III. (1992). Being different: Relational demography and organizational attachment. Administrative Science Quarterly, 37, 549-579.

Van Rheenen, G. (2006). Contrasting missional and church growth perspectives. Restoration Quarterly, 48, 25-32. 


\section{Authors}

David R. Dunaetz is an assistant professor of organizational psychology at Azusa Pacific University. He spent 17 years as a church planter in France. He has degrees from Harvey Mudd College, U.S.C., Denver Seminary, Fuller Theological Seminary, University of Paris-La Sorbonne, and Claremont Graduate University. The primary focus of his research concerns conflict processes in Christian organizations.

Kenneth E. Priddy is a church vitality trainer and consultant serving numerous evangelical denominations. His pastoral history includes both church planting and church revitalization. He holds degrees from Virginia Commonwealth University, Reformed Theological Seminary, and Newburgh Theological Seminary. The central thrust of his ministry is to move churches toward greater vitality through a Great Commission commitment to outreach and evangelism, leading to disciples who make disciples. 